\title{
PECULIARITIES OF LASER WELDING OF METALS
}

\author{
Br. Petrètis ${ }^{\mathrm{a}, \mathrm{b}}$ and M. Balčiūnienè ${ }^{\mathrm{a}}$

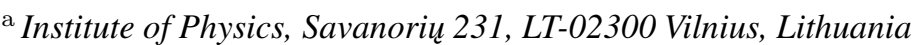 \\ E-mail: brpet@delfi.lt

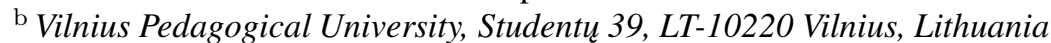

Received 20 October 2004

\begin{abstract}
The work analyses the main thermal and physical parameters of the material that condition the laser welding process. It is shown that the best quality of the laser welding seam in carbon-rich and highly doped steels is obtained when the seam is formed from the covering layer of the powder mixture deposited on the surface of the welded parts. It should be noted that, when the laser technology is used to weld the parts from copper or aluminium, the welding process can be carried out in the atmosphere of $\mathrm{CO}_{2}$ gas.
\end{abstract}

Keywords: laser welding, metal science, steel, laser technology

PACS: $68.55 .-\mathrm{a}$

\section{Introduction}

The welding is often used for connection of metallic components of constructions. The advantage of this method lies in large productivity and economy.

Since the introduction of lasers they are widely used in various technological processes of metal treatment, such as heat treatment, cutting, perforation of holes, evaporation of films, doping with the admixtures, synthesis of the alloys as well as welding [1-4]. Laser technologies are characterized by a number of advantages occupying a special position in industry.

The use of the laser technology in the works of metal welding increased the efficiency and reliability of this technological process and also broadened application of this method [1,4]. The laser welding method can be used efficiently for the precision welding of small or sheet parts. The physical processes that occur in the welding seam are analogous to those that take place in the covering layer of an item during the laser doping of this layer with admixtures $[5,6]$.

The laser welding process has been quite well analysed theoretically by modelling the fields of temperature [7-9] and experimentally when the quality of the welding seam under various technological conditions has been investigated $[10,11]$. The technological process of laser welding is under constant development. The laser welding method was investigated in the past years when a laser beam was split into two equal power beams [12-13]. It is proved that in some cases this method gives positive results. As shown in [14], the rate and stability of the process increase by using a metal powder filler.

The welding of highly doped steels, aluminium, and copper is still problematic up to now. When the parts of these metals are welded, metal oxides are being formed in the welding seam. Besides, due to temperature deformation in the highly doped steel, large thermal stresses occur there, which cause formation of microcracks in the welding seam and around. These phenomena make it difficult to obtain a quality welding seam. Sometimes the elements made of these metals are used in electronics and microelectronics. It would be convenient to have a possibility to connect these metals by welding. For this purpose the laser technology can be used. So, the investigation of some technological problems when the metal parts are welded by laser is presented in this work.

\section{Experimental}

Experiments of part welding were carried out at room temperature by pulsed YAG:Nd laser irradiation in the atmosphere of $\mathrm{CO}_{2}$ gas $[5,15]$. The light pulse duration was $4 \mathrm{~ms}$, and the energy was changed from 2 up to $10 \mathrm{~J}$. The power $q_{k}$ per unit of the sample surface area was changed from 100 to $1000 \mathrm{~kW} / \mathrm{cm}^{2}$. At the same time the level of the laser beam focusing was also changed. The experiments of welding were carried 


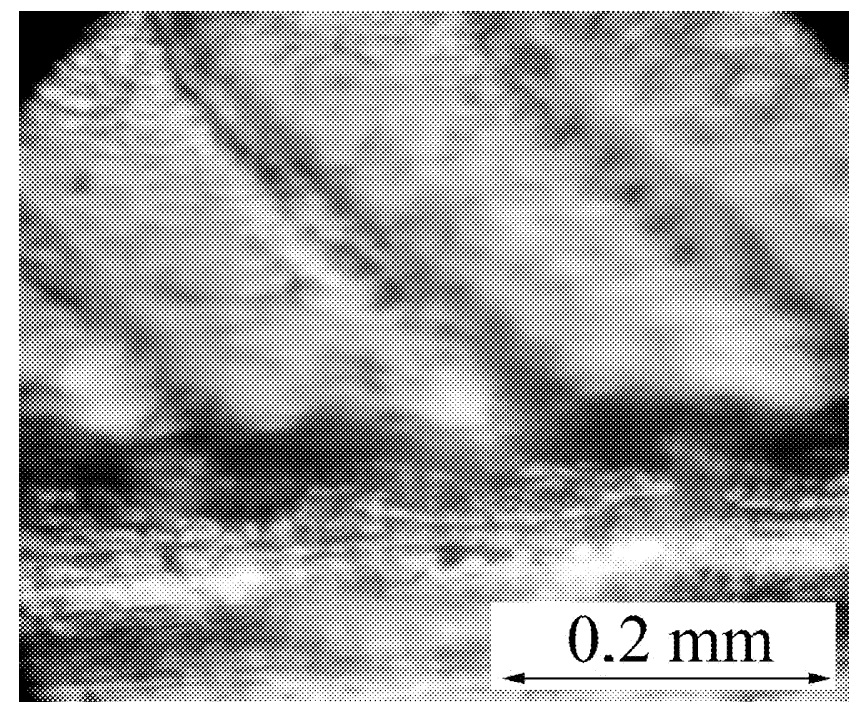

(a)

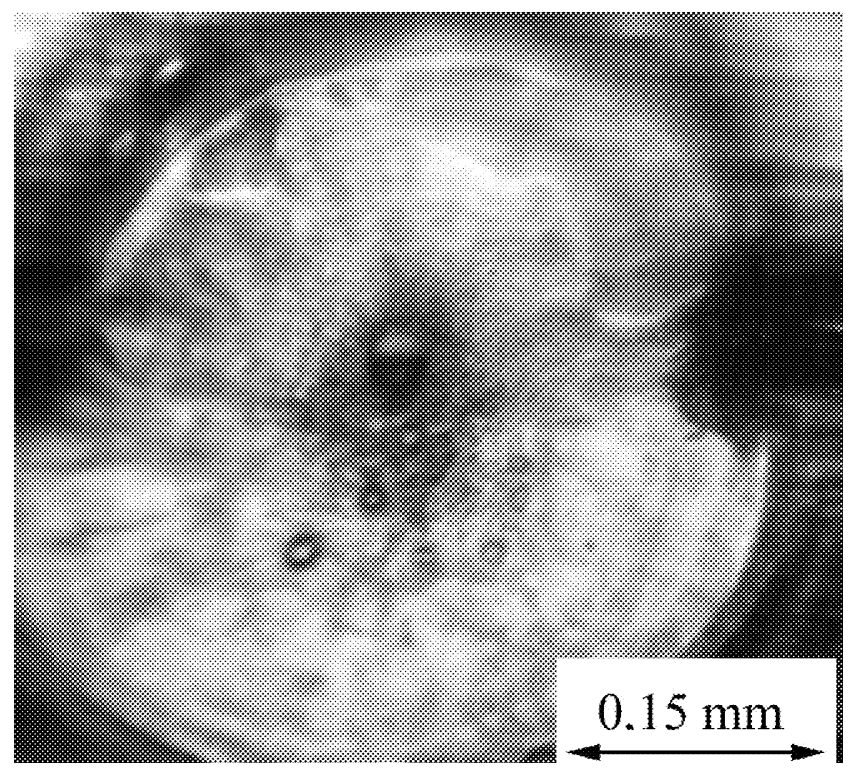

(b)

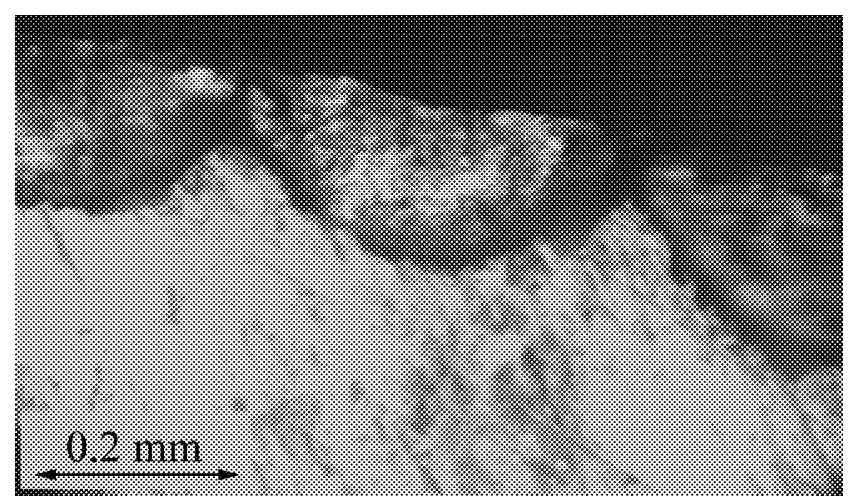

(c)

Fig. 1. Microphotographs of the laser welding seams of $(a, c)$ the steel parts with a low quantity and (b) average quantity of carbon, (c) cross-section of the welding seam after its destruction by forming tangential stresses.

out with lowly and highly doped steels rich or poor in carbon (Table 1) and with the parts of technically pure copper and aluminium.

The parts of steel were plates from 0.5 up to $3 \mathrm{~mm}$ thick, the parts of copper or aluminium were sheets up to $1 \mathrm{~mm}$ thick, or a wire with a diameter up to $1 \mathrm{~mm}$. In some cases the weld was formed from the powder mixture which was placed on the surface of the parts at their connection. The main component of the powder mixture was iron particles of size up to $5 \mu \mathrm{m}$, and the rest was the powder of carbon or boron. The powder was mixed with a small quantity of liquid glass $(<3 \mathrm{wt} \%)$.

\section{Results}

Laser welding can be used for different materials the thickness of which varies from several micrometres up to some millimetres. The main controlled parameter of laser irradiation is the power density, which for the welding operations is restricted by the upper and the lower limits. When the upper limit is exceeded, the material begins to boil and evaporate intensively, so that the metal is sprayed out from the bath, forming defects in the welding seam. The lower limit of the power density is determined by melting temperature of metals $T_{1}$ (Table 2).

The steels which are poor in carbon (when the concentration of carbon does not exceed $0.2 \%$ ) and low doped (Table 1, group 1) can be welded by laser irradiation well: the welding seam is formed easily and without any considerable defects (Fig. 1(a)). This is determined by comparatively large plasticity of this metal, which considerably accelerates the relaxation of the residual thermal stresses in the vicinity of the welding seam. 
Table 1. The chemical composition of the steel parts, $\% . N_{\mathrm{a}}$ is richness in carbon, $N_{\mathrm{d}}$ is doping of the alloy.

\begin{tabular}{cccccccc}
\hline Groups of steels & $\mathrm{C}$ & $\mathrm{Mn}$ & $\mathrm{Si}$ & $\mathrm{Cr}$ & $\mathrm{Fe}$ & $N_{\mathrm{a}}$ & $N_{\mathrm{d}}$ \\
\hline 1 & 0.17 & 0.40 & 0.05 & 0.15 & rest & low & low \\
2 & 0.19 & 0.29 & 0.29 & 12.7 & rest & low & high \\
3 & $0.39-0.40$ & $0.3-0.5$ & $0.3-0.5$ & $12-13.5$ & rest & average & high \\
4 & 0.9 & 0.39 & 0.30 & 1.6 & rest & high & average \\
\hline
\end{tabular}

Table 2. The physical parameters of some materials which are important for laser technology $[16,17] . R$ is the reflection coefficient of laser irradiation, $T_{1}$ is the melting temperature, $\lambda_{T}$ is the coefficient of heat conductivity, $C_{V}$ is the heat capacity, $a_{T}$ is the temperature coefficient of conductivity, $\alpha$ is the coefficient of linear thermal expansion.

\begin{tabular}{ccrcccc}
\hline Metals & $R(\lambda=1.06 \mu \mathrm{m})$ & $T_{1}, \mathrm{~K}$ & $\lambda_{T}, \mathrm{~W} \cdot \mathrm{m}^{-1} \cdot \mathrm{K}^{-1}$ & $C_{V}, 10^{6} \mathrm{~J} \cdot \mathrm{m}^{-3} \cdot \mathrm{K}^{-1}$ & $a_{T}, 10^{-5} \mathrm{~m}^{2} / \mathrm{s}$ & $\alpha, 10^{-6} \mathrm{~K}^{-1}$ \\
\hline $\mathrm{Al}$ & $92-95$ & 932 & 218 & 2.44 & 8.93 & 22.9 \\
$\mathrm{Cu}$ & $93-96$ & 1356 & 399 & 3.49 & 11.43 & 16.7 \\
Steel & $60-65$ & 1812 & 75.4 & 3.50 & 2.13 & $10-16$ \\
\hline
\end{tabular}

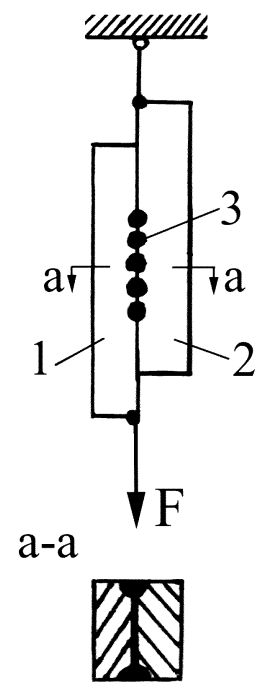

Fig. 2. Measurement scheme of the strength of the laser welding seam: 1,2 are the welded parts, 3 is the welding seam by points.

The strength of the loaded welding seam was investigated. Two parts, welded by laser, were fixed on the hinge and loaded with power $F$ (Fig. 2). The loading power is increased up to destruction of the welding seam. The welding seam for these investigations is formed as follows: laser irradiation pulses, from 5 up to 15 (Fig. 2, section a-a), act on both sides of the plates. The destroyed section of the welding seam is analysed with a microscope and the common area of the destroyed cross-section is determined (Fig. 1(c)). Then the strength of the welding seam for shearing load is calculated. It is determined that the value of tangential stresses strength of the welding seam is 350-400 MPa. It makes up 0.75-0.8 $\sigma_{\mathrm{T}}$, where $\sigma_{\mathrm{T}}$ is the yield limit of that group of steels [17]. This value about three times exceeds the permissible stresses of shearing for this material.

Steel that is poor in carbon, but highly doped with chromium, is welded like the first group steels (Table 1, group 2), see Fig. 1(b).

The region of the hardened steel is formed in the welding seam and around it, when the highly doped steels (with the total concentration of doping elements more than $10 \%$ and the quantity of carbon up to $0.3-0.45 \%$ ) are welded. This region is characterized by higher hardness and at the same time by brittleness and tendency for crack formation (Fig. 3(a)). When the power density of laser irradiation is close to the upper limit $\left(q_{k}\right.$ is equal to $\left.180-200 \mathrm{~kW} / \mathrm{cm}^{2}\right)$ the indications of the melt boiling are observed - large drops of the melt are formed in the surroundings of the welding seam. When the welded parts are acted by ultrasound waves (frequency $f$ is equal to $40 \mathrm{kHz}$, the vibration amplitude $A$ is equal to $1.5 \mu \mathrm{m}$, and duration of action $t$ is equal to $5 \mathrm{~min}$ ) the cracks of the seam are revealed (Fig. 3(a)).

In the carbon-rich steels with the carbon concentration up to $0.6-0.9 \%$ and the concentration of other doping elements exceeding $10 \%$ (Table 1 , group 4 ), the main problem of their welding is the formation of the cracks in the welding seam and its region (Fig. 3(a)). Use of the laser welding technology easily provides conditions to change the concentration of doping admixtures in the welding seam. For example, when these steels are welded the seam can be formed from a properly chosen powder mixture (Fig. 3(c, d)). The plasticity of the welding seam increases and the internal thermal stresses relax due to the plastic properties of the alloy and nonmetallic insertions. 


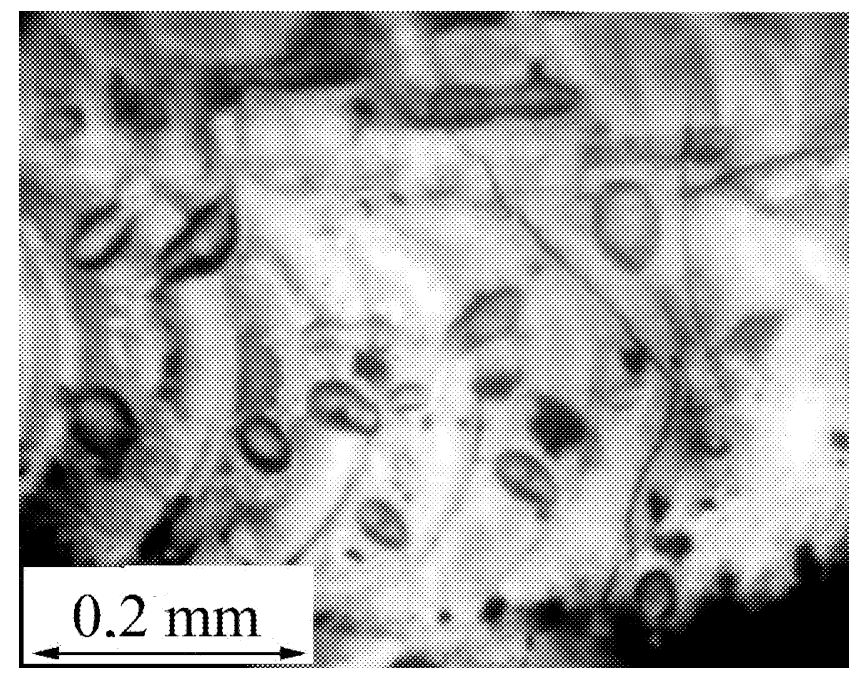

(a)

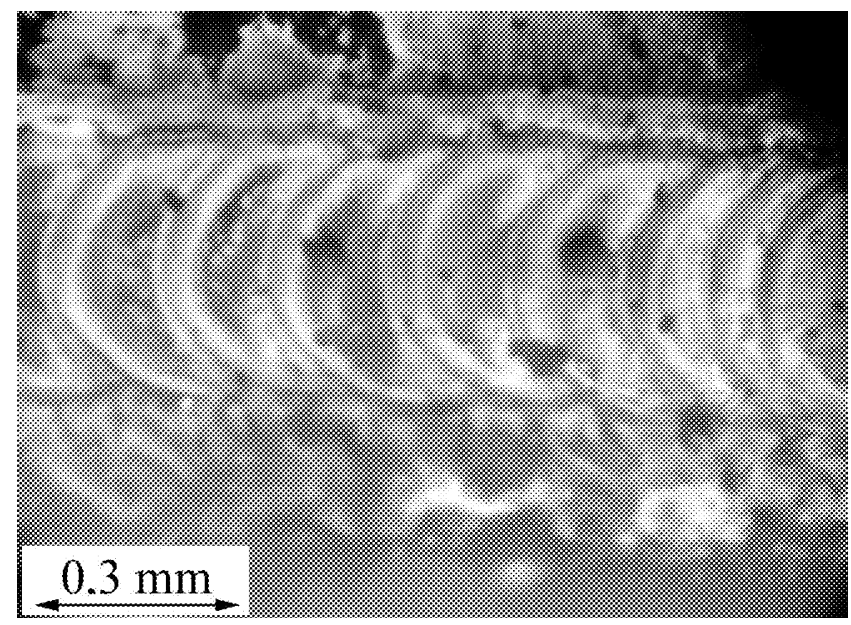

(c)

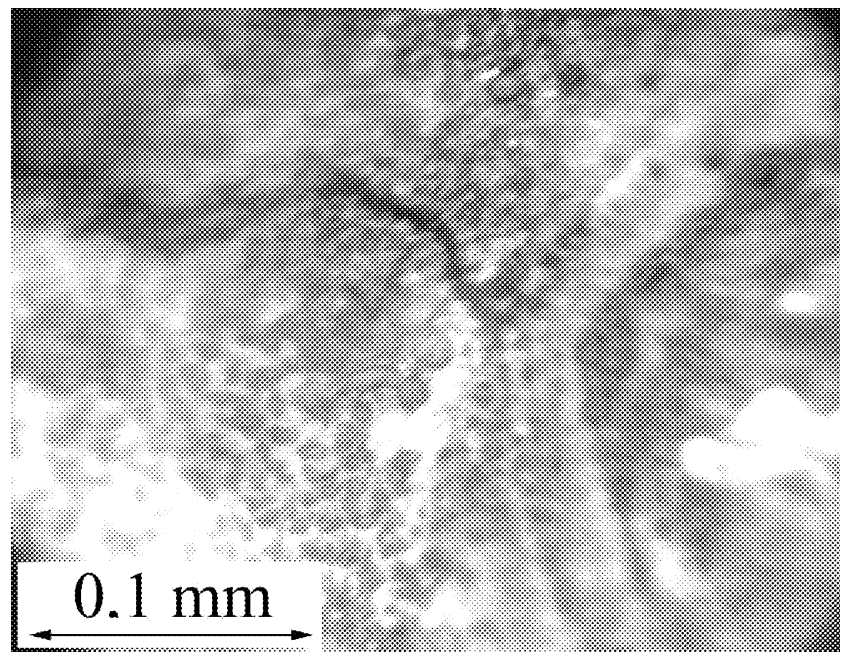

(b)

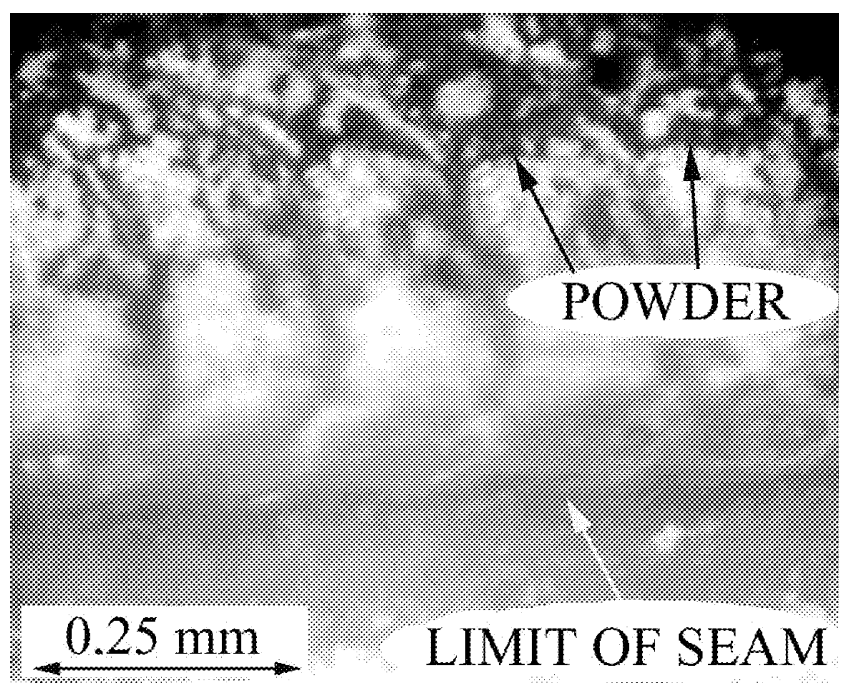

(d)

Fig. 3. Microphotographs of the laser welding seams of the steel parts with a high quantity of carbon: (a) microcracks in the seam, (b) welding seam acted by ultrasound waves ( $f$ is equal to $40 \mathrm{kHz}$ and the amplitude of the ultrasound waves $A$ is equal to $1.5 \mu \mathrm{m}$ ), (c, d) the seam is formed from the powder mixture (B is 15 at.\%, the rest is $\mathrm{Fe}$ ).

As known [18-20], welding of nonferrous metals, for example, aluminium or copper, causes oxidation of the metal surface. Thus, the film of oxide is formed that has melting temperature $T_{1}$ considerably different from the main metal (for example, $T_{1}$ of $\mathrm{Al}_{2} \mathrm{O}_{3}$ is equal to $2270 \mathrm{~K}$ ). The particles of nonmelted oxide can be formed in the welding seam and they may decrease the strength and quality of the welding seam. So, Al, $\mathrm{Cu}$, and their alloys are welded in the atmosphere of protective gas (He, Ar, and other). As the laser welding process is very fast, this operation can be successfully carried out in the atmosphere of $\mathrm{CO}_{2}$ gas as well (Fig. 4).

Copper and aluminium are characterized by a high value of the reflection coefficient (especially in the re- gion of infrared rays). For this reason the lower limit of the power density of laser irradiation is reached only when the power density of the incident beam $q_{k}$ is large enough. Other heat parameters, such as the coefficient of heat conductivity $\lambda_{T}$, the heat capacity $C_{V}$, and the temperature coefficient of conductivity $a_{T}$, have large influence on the lower limit of the power density (Table 2).

\section{Discussion}

Using the YAG:Nd lasers, the surface of the steel is melt with $q_{k}$ being equal to $130-150 \mathrm{~kW} / \mathrm{cm}^{2}$. For the melt of aluminium $q_{k}$ must be $400-600 \mathrm{~kW} / \mathrm{cm}^{2}$, and 


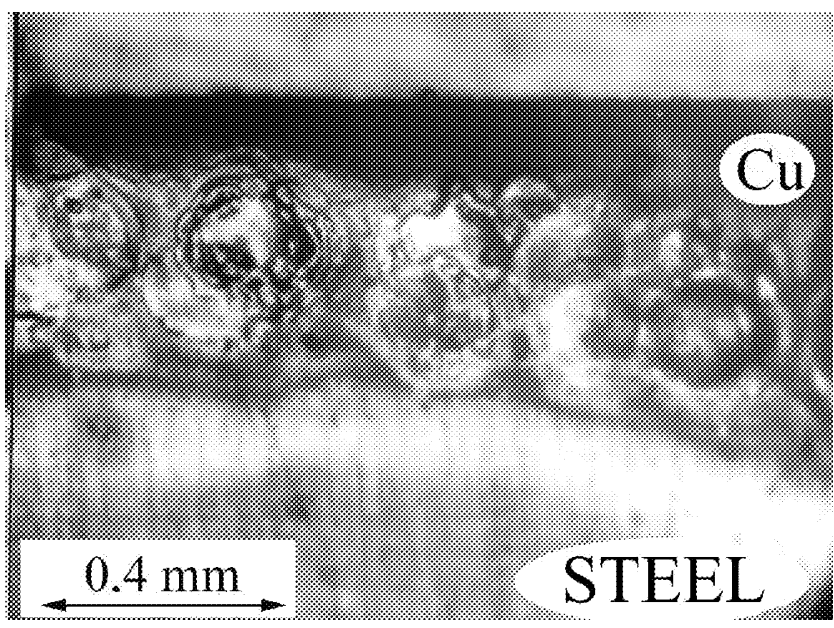

(a)

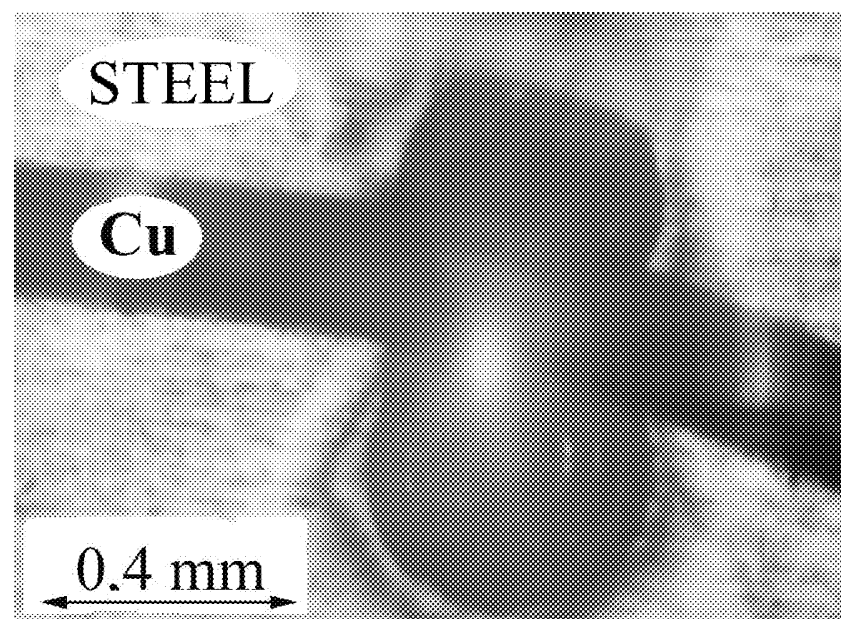

(b)

Fig. 4. Microphotographs of (a) copper sheet and (b) copper wire welded to steel plate.

for copper $800-1000 \mathrm{~kW} / \mathrm{cm}^{2}$. So, welding of these metals' parts of larger dimensions requires lasers with the power higher than $0.5 \mathrm{~kW}$.

One of peculiarities of the laser welding is that the welding seam cools very quickly (at $10^{6}-10^{7} \mathrm{~K} / \mathrm{s}$ ). This causes very large gradients and, respectively, internal stresses. The magnitude of residual stresses depends on the coefficient of thermal expansion $\alpha$. As the coefficients $\alpha$ of copper and aluminium are considerably higher than those of the steel (Table 2), welding of these materials with steel parts causes the formation of large stresses in the welding seam due to different thermal expansion. The most efficient method to solve this problem is to heat the part up to the temperature of the martensitic transformation. With the welded part cooling down slowly, the stresses relax due to transformation plasticity, and the quality of the seam considerably improves.

The analysis of thermophysical models and the experimental results of laser welding show that the main parameters, just like in other processes of laser technology, are the power density of absorbed laser irradiation, the duration of the action, and the composition of the protective gas. The welding seam of high quality is formed only in the case when the power density of absorbed laser irradiation is sufficient to melt the material of both connected parts. The power density absorbed in the material, and the energy, also depend not only on the power of incident laser irradiation, but on the material reflection coefficient $R$ (Table 2) of laser irradiation, too. The value of $R$ depends on the nature of the material, the wavelength of laser irradiation, and the temperature $[16,17]$. It has to be noted that the absorption of laser irradiation considerably increases when the material is heated up to the melting temperature $T_{1}$, and then melts. Absorbed energy depends on the preparation of the surface, too.

When a copper wire is welded to a plate of steel and the laser irradiation is absorbed directly by the surfaces of copper and steel, the steel plate, due to the higher $R$ value, melts earlier than the copper wire. So, the copper wire is alloyed in the bath of the steel melt and in this bath it partly or completely melts (Fig. 4(a)). Such welding is sufficiently stable and reliable.

\section{Conclusions}

1. The tangential stress strength limit of laser welding seam of the poor in carbon steel parts amounts up to $400 \mathrm{MPa}$.

2. In the welding seams of the carbon-rich steels internal stresses cause the formation of microcracks, which develop into the cracks of the seam under the action of vibration loads.

3. It is expedient to form the laser welding seam for carbon-rich and highly doped steels from a powder mixture of iron and low concentration (up to 20-30 at.\%) of doping elements (i. e. carbon and boron).

4. When the nonferrous metals $(\mathrm{Cu}$ and $\mathrm{Al})$ are welded by laser irradiation, apart from the properties of oxidation, the physical properties of the metals (the reflection coefficient of laser irradiation $R$, the coefficient of heat conductivity $\lambda_{T}$, the coefficient of thermal expansion $\alpha$ ) are of great importance. 


\section{References}

[1] W.W. Duley, Laser Processing and Analysis of Materials (Plenum Press, New York/London, 1983) p. 504.

[2] A.G. Grigoriyants, Fundamentals of Laser Treatment of Materials (Mashinostroyeniye, Moscow, 1989) p. 304.

[3] R.A. Willgoss, J.H.P.C. Megaw, and J.M. Clark, Laser welding of steels for power plant, Opt. Laser Technol. 11(2), 73-81 (1979).

[4] V.M. Andriyakhin, Processes of Laser Welding and Heat Treatment (Nauka, Moscow, 1988) p. 176.

[5] A. Amulevičius, M. Balčiūnienè, and Br. Petrètis, Iron doped by carbon under the influence of laser irradiation, Lithuanian J. Phys. 33(4), 227-232 (1993).

[6] H.E. Cline and T.R. Anthony, Heat treating and melting material with a scanning laser or electron beam, J. Appl. Phys. 48(9), 3895-3900 (1977).

[7] M. Aden, E. Beyer, and G. Herziger, Laser induced vaporization of a metal surface, J. Phys. D 25(1), 57-65 (1992).

[8] P.G. Klemens, Heat balance and flow conditions for electron beam and laser welding, J. Appl. Phys. 47(5), 2165-2176 (1976).

[9] M.R. Frewin and D.A. Scott, Finite element model of pulsed laser welding, Welding J. 78(2), 15-22 (1999).

[10] J. Xie and A. Kar, Laser welding of thin sheets steel with surface oxidation, Welding J. 78(11), 137-141 (1999).

[11] S. Missory, F. Murdalo, and A. Sili, Single-pass laser beam welding of clad steel plates, Welding J. 83(2), 66-71 (2004).
[12] J. Xie, Dual beam laser welding, Welding J. 78(6), 223-231 (1999).

[13] Y.N. Liu and E. Kannatey-Asibu Jr., Experimental study of dual beam laser welding of AISI 4140 steel, Welding J. 76(9), 342-348 (1997).

[14] S. Missory and A. Sili, Structural characterization of C-Mn steel laser beam welded joints with powder filler metal, Welding J. 79(10), 317-323 (2000).

[15] Br. Petrètis and M. Balčiūnienè, Kinetics of alloying powder mixtures by laser technology, Lithuanian $\mathrm{J}$. Phys. 43(4), 291-296 (2003).

[16] K.I. Krylov, V.T. Prokopenko, and A.S. Mitrofanov, Application of Lasers in Mechanical Engineering and Instrument-Making (Mashinostroyeniye, Leningrad, 1978) p. 336.

[17] Tables of the Physical Quantities, Reference Book, ed. I.K. Kikoin (Atomizdat, Moscow, 1978) p. 1008.

[18] E. Biro, D.C. Weckman, and Y. Zhou, Pulsed Nd:YAG laser welding of copper using oxygenated assist gases, Metallurgical Material Trans. 33A(7), 2002-2019 (2002)

[19] H. Zhao and T. Debroy, Weld metal composition change during conduct mode laser welding of aluminium alloy 5182, Metallurgical Material Trans. 33B(2), 163-172 (2001).

[20] T. Forsman, A.F.H. Kaplan, J. Powell, and C. Magnusson, Initiation and termination phenomena in laser welding of aluminium, J. Laser Appl. 12(2), 81-88 (2000).

\title{
LAZERINIO METALŲ SUVIRINIMO YPATUMAI
}

\author{
Br. Petrètis ${ }^{\mathrm{a}, \mathrm{b}}, \mathrm{M}$. Balčiūniené ${ }^{\mathrm{a}}$ \\ ${ }^{a}$ Fizikos institutas, Vilnius, Lietuva \\ ${ }^{\mathrm{b}}$ Vilniaus pedagoginis universitetas, Vilnius, Lietuva
}

\section{Santrauka}

Analizuojami pagrindiniai šiluminiai ir fizikiniai medžiagos parametrai, kurie sąlygoja lazerinio suvirinimo procesą. Parodyta, kad didelio anglingumo ir daug legiruotuose plienuose geresnè la- zerinio suvirinimo siūlès kokybẻ yra gaunama, kai siūlè sudaroma iš padengimo miltelių mišinių sluoksnio. Reikia pažymèti, kad naudojat lazerinę technologija vario ir aliuminio elementams suvirinti, tai galima sėkmingai atlikti $\mathrm{CO}_{2}$ dujų atmosferoje. 